\title{
A 2016-ban publikált új ESC szívelégtelenség irányelv krónikus szívelégtelenség diagnózisára és kezelésére vonatkozó ajánlásai
}

\author{
Nyolczas Noémi
}

\author{
Magyar Honvédség Egészségügyi Központ, Kardiológia Osztály, Budapest
}

Levelezési cím: Dr. Nyolczas Noémi, 1134 Budapest, Róbert Károly krt. 44., E-mail: nyolczasnoemi@gmail.com

\begin{abstract}
Jelen közlemény áttekintést kiván adni az új, 2016-ban publikált ESC szívelégtelenség irányelv általános fejezeteinek újdonságairól (új terminológia, új diagnosztikus kritériumok, a krónikus szívelégtelenség új diagnosztikus algoritmusa, az új irányelv szívelégtelenséget megelőző állapotok megfelelő ellátásával foglalkozó új fejezete); bemutatja az új irányelv HFrEF gyógyszeres kezelésére vonatkozó ajánlásait, és összehasonlítja ezeket a korábbi 2012-ben publikált ESC szívelégtelenség irányelv, valamint a korábbi 2013-ban publikált amerikai (ACCF/AHA) szívelégtelenség irányelv és az elmúlt évben megjelent amerikai irányelv-megújitás ajánlásaival; valamint összefoglalja a HFrEF eszközös kezelésére és a HFpEF terápiájára vonatkozó újdonságokat.
\end{abstract}

Kulcsszavak: szívelégtelenség, irányelv, gyógyszeres kezelés, eszközös kezelés

Recommendations for the diagnosis and treatment of chronic heart failure in the new ESC heart failure guidelines published in 2016

This paper intends to provide an overview of the novelties in the general chapters of the new ESC heart failure guidelines published in 2016: the new terminology, the new diagnostic criteria, the new diagnostic algorithm in chronic heart failure and the new chapter dealing with prevention or delay of the development of overt heart failure. In addition, the article presents the recommendations of the new ESC heart failure guidelines for the pharmacological therapy of HFrEF and compares them with the recommendations of previous ESC heart failure guidelines published in 2012, with previous ACCF/AHA guidelines recommendations published in 2013 and with the recommendations of ACC/AHA/HFSA focused update on new pharmacological therapy for heart failure published in 2016. Finally, the publication summarizes the novelties of the device therapy (CRT and/or ICD) of HFrEF and treatment of HFpEF.

Keywords: heart failure, guidelines, pharmacological therapy, device therapy

\section{Bevezetés}

Az Európai Kardiológus Társaság 2016-ban új irányelvet publikált az akut és krónikus szívelégtelenség diagnózisát és terápiáját illetően (1). Ugyancsak 2016-ban az amerikai kardiológus társaságok (ACC/AHA/HFSA) is megújították a 2013-ban publikált szívelégtelenség irányelv gyógyszeres kezelésre vonatkozó fejezetét (2). Jelen közlemény foglalkozik az új ESC-irányelv általános fejezeteinek újdonságaival (az új terminológiával, az új diagnosztikus kritériumokkal, a krónikus szívelég- telenség új diagnosztikus algoritmusával, az új irányelv szívelégtelenséget megelőző állapotok megfelelő ellátásával foglalkozó új fejezetével); bemutatja az új irányelv HFrEF gyógyszeres kezelésére vonatkozó ajánlásait és összehasonlítja azokat a korábbi 2012-ben publikált ESC szívelégtelenség irányelv (3), valamint a korábbi 2013-ban publikált amerikai (ACCF/AHA) szívelégtelenség irányelv (4) és az elmúlt évben megjelent amerikai irányelv megújítás (2) ajánlásaival; valamint összefoglalja a HFrEF eszközös kezelésére és a HFpEF terápiájára vonatkozó újdonságokat. 


\section{A szívelégtelenség ưj terminológiảja}

Az új ESC-irányelv a csökkent ejekciós frakciójú szívelégtelenség (HFrEF) és a megtartott ejekciós frakciójú szívelégtelenség (HFpEF) mellett bevezette a közepes ejekciós frakciójú szívelégtelenség (HFmrEF) fogalmát. Az új definíció szerint HFrEF-ről beszélünk, ha a bal kamrai ejekciós frakció (LVEF) 40\% alatti, HFpEF-ről, ha a LVEF $50 \%$, vagy afeletti, s HFmrEF-röl, ha a LVEF értéke a kettő között van. Eddig is ismert volt, hogy a HFrEF és a HFpEF közötti határt nem lehet egy meghatározott bal kamrai ejekciós frakció (LVEF) értékkel definiálni. Ismert, hogy a kettő között van egy szürke zóna, amit nem lehet egyértelműen sem HFrEF-ként, sem HFpEF-ként definiálni. Ezt a szürke zónát nevezte el az új ESC-irányelv HFmrEF-nek. A HFmrEF természetesen nem jelent új patofiziológiai entitást, az ide tartozó betegek is döntően vagy HFrEF, vagy HFpEF patofiziológiát mutatnak. A HFmrEF jelenleg egy meglehetősen heterogén betegcsoportot jelöl. Ide tartoznak azok a betegek, akik korábban a HFrEF-csoportba tartoztak, de a megfelelö gyógyszeres és szükség szerint eszközös kezelés hatására bekövetkező LVEF-javulás következtében a HFmrEF-kategóriába kerültek. Ide tartoznak azok a betegek, akik korábban a HFpEF-csoportba tartoztak, de a betegség progressziója miatt a HFpEF-betegek esetében megtartott LVEF mellett is mindig jelenlévő kontraktilitási zavar olyan mértékben progrediált, hogy a LVEF $50 \%$ alá csökkent. S ide tartozik valamennyi olyan beteg, akinek a szívelégtelenség diagnózisakor 40 és $50 \%$ közötti LVEF-je van. Jelenleg a HFpEF-csoporthoz hasonlóan a HFmrEF-betegekről is meglehetősen keveset tudunk, mind az epidemiológiát, mind a kezelést illetően.

\section{Új diagnosztikus kritériumok (1. táblázat)}

Az új ESC-irányelv alapján a HFrEF diagnózisához csupán két kritérium szükséges, a szívelégtelenségre jellemző tünetek és panaszok jelenléte, valamint a $40 \%$ alatti LVEF. A HFmrEF és a HFpEF diagnózisához azonban a szívelégtelenségre jellemző tünetek és panaszok meglétén, valamint a HFpEF esetén az 50\% vagy afeletti LVEF-n és HFmrEF esetén a 40 és $50 \%$ közötti LVEF-en túl további két kritérium fennállása szükséges. Az egyik a strukturális szívbetegség (balkamra-hipertrófia és/vagy bal pitvar dilatáció) vagy a diasztolés balkamra-diszfunkció valamilyen képalkotó módszerrel (az esetek többségében echokardiográfiával) történő igazolása, a másik az emelkedett nátriuretikus peptidszint. Ez utóbbi NTproBNP esetén $125 \mathrm{pg} / \mathrm{ml}$, BNP esetben $35 \mathrm{pg} / \mathrm{ml}$ feletti értéket jelent.

\section{Új diagnosztikus algoritmus krónikus szívelégtelenségben}

Az új ESC-irányelv új diagnosztikus algoritmust dolgozott ki krónikus szívelégtelenségben (1. ábra). Az új diagnosztikus algoritmus alapján a különböző rendelkezésre álló információkra támaszkodva a szívelégtelenség fennállásának valószínűségét határozhatjuk meg.

Az irányelv első lépésként a beteg anamnézisének, fizikális vizsgálati eredményeinek és EKG-jának értékelését javasolja. Amennyiben a beteg anamnézisében nem szerepel koronáriabetegség, hipertónia, nem alkalmazott, vagy nem volt kitéve kardiotoxikus szereknek, vagy irradiációnak, nem szorul diuretikum kezelésre, nincsenek orthopnoes, vagy paroxizmális nocturnalis dyspnoes panaszai, ha fizikális vizsgálata során nem észlelünk pulmonalis pangást, nincs kétoldali alsó végtagi ödémája, nincs szívzöreje, nincsenek dilatált vena jugularisai, nincs lateral felé helyezett szívcsúcslökése és az EKG-ja normális a szívelégtelenség fennállásának valószínűsége olyan alacsony, hogy a szívelégtelenség diagnózisa elvethető. Amennyiben a fenti tényezők közül egy is pozitív, úgy az irányelv következő lépésként a nátriuretikus peptidszint-meghatározást javasolja. Ha a BNP-szint kisebb, mint $35 \mathrm{pg} / \mathrm{ml}$, vagy az NTproBNP-szint alacsonyabb, mint $125 \mathrm{pg} / \mathrm{ml}$, abban az esetben a szívelégtelenség fennállásának alacsony valószínüsége miatt a szívelégtelenség diagnózisa elvethető. Ha a nátriuretikus peptidek szintje a fenti értékekkel egyenlő, vagy annál magasabb úgy echokardiográfia elvégzése javasolt, részben a szívelégtelenség diagnózisának megerősítése, részben a szívelégtelenség típusának (HFrEF, HFmrEF, HFpEF) megállapítása céljából. Ha a nátriuretikus peptidszint-meghatározás nem elérhető (mint Magyarországon az ellátóhelyek többségében), akkor minden olyan beteg esetében,

\section{TÁBLÁZAT. Diagnosztikus kritériumok HFrEF-ben, HFmrEF-ben és HFpEF-ben}

\section{HFrEF}

Szívelégtelenségre jellemző panaszok \pm tünetek

LVEF $<40 \%$

\section{HFmrEF}

Szívelégtelenségre jellemző panaszok \pm tünetek

$40 \% \leq \mathrm{LVEF}<50 \%$

Emelkedett nátriuretikus peptidszint

Releváns strukturális szívbetegség és/vagy bal kamrai diasztolés diszfunkció kimutatása

\section{HFpEF}

Szívelégtelenségre jellemző panaszokıtünetek

LVEF $\geq 50 \%$

Emelkedett nátriuretikus peptidszint

Releváns strukturális szívbetegség és/vagy bal kamrai diasztolés diszfunkció kimutatása

HFrEF: csökkent ejekciós frakciójú szívelégtelenség, HFmrEF: közepes ejekciós frakciójú szívelégtelenség, HFpEF: megtartott ejekciós frakciójú szívelégtelenség, LVEF: bal kamrai ejekciós frakció 


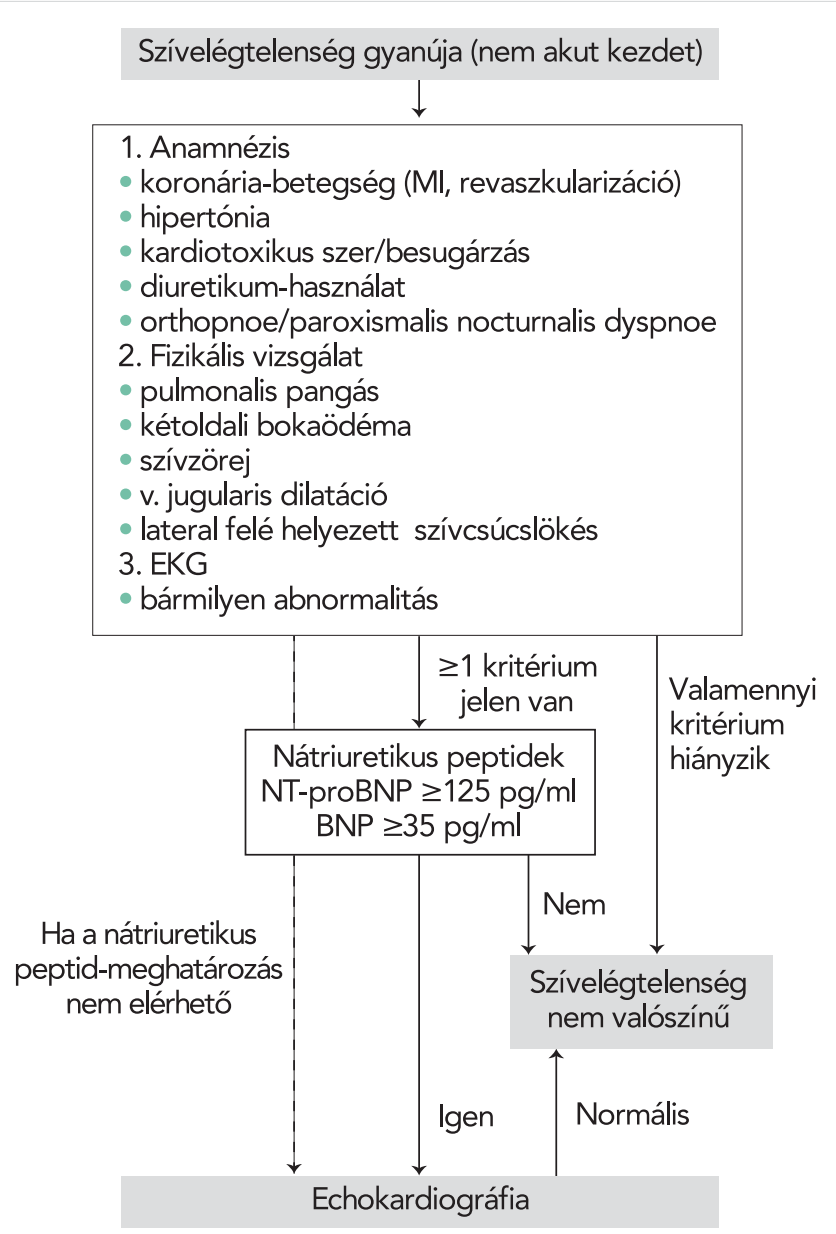

1. ÁBRA. A krónikus szívelégtelenség diagnosztikus algoritmusa

akinél az anamnézis, a fizikális vizsgálat és az EKG értékelése során egy tényező is pozitív echokardiográfia elvégzése szükséges.

Amennyiben a fenti vizsgálati algoritmust követve a szívelégtelenség diagnózisa bizonyítást nyert, nagyon fontos az etiológia meghatározása és a társbetegségek diagnózisa, hiszen a szívelégtelenség csak ezek ismeretében kezelhető megfelelően.

\section{Az új irányelv szívelégtelenséget megelőző állapotokkal foglallkozó új fejezete}

Az amerikai kardiológus társaságok (ACC/AHA) szívelégtelenségre vonatkozó irányelvei már hosszú évek óta külön fejezetekben foglalkoznak a szívelégtelenséget megelőző állapotokkal („A” és „B” stádium) és ezek megfelelő kezelésével. Az ESC szívelégtelenség irányelve most első alkalommal szentel önálló fejezetet ennek a nagyon fontos kérdésnek.

Az új irányelv I. osztályú ajánlásként javasolja a hipertónia megfelelő kezelését; a statinok alkalmazását koronáriabetegekben, illetve koronáriabetegség szempont- jából magas rizikójúaknak; valamint a dohányzásról és a túlzott alkoholfogyasztásról való leszoktatást. II.a ajánlást fogalmaz meg a szívelégtelenség egyéb rizikófaktorainak (obesitas, dysglykaemia) megfelelő kezelését illetően.

Az EMPAREG-OUTCOME-vizsgálat (5) eredményeinek 2015-ös publikálását követően az új irányelv minden diabéteszes beteg esetében javasolja az empagliflozin alkalmazásának megfontolását (II.a ajánlás). Bár az orális antidiabetikumokra vonatkozó gyógyszerhatósági (FDA, EMA) biztonsági követelményeknek ma már számos új orális antidiabetikum megfelel, mind a mai napig az empagliflozin az egyetlen, ami szignifikánsan csökkenti a szívelégtelenség miatti hospitalizáció rizikóját.

Az új irányelv tünetmentes szisztolés balkamra-diszfunkció esetén miokardiális infarktust követően, illetve anélkül ACE-inhibitor (ACEi) alkalmazását javasolja (I. osztályú ajánlás). Bétareceptor-blokkolót (BB) csak miokardiális infarktust követően kialakuló tünetmentes szisztolés balkamra-diszfunkció esetén javasol (I. osztályú ajánlás). Tény, hogy evidencia csak erre a betegcsoportra van (CAPRICORN-vizsgálat) (6). Figyelembe véve azonban a betegség patomechanizmusát és a BB-k farmakológiai tulajdonságait feltételezhető a BB-k kedvező hatása megelőző miokardiális infarktus nélkül kialakuló tünetmentes szisztolés balkamra-diszfunkció esetén is. A 2013-ban publikált amerikai (ACCF/AHA) szívelégtelenség irányelv a BB-k alkalmazását ebben a klinikai szituációban I. osztályú ajánlásként javasolja.

Az új irányelv II.a osztályú ajánlást fogalmaz meg az ACEi-k alkalmazását illetően koronáriabetegség fennállása esetén bal kamra szisztolés diszfunkció nélkül.

I. osztályú ajánlásként szerepel az új irányelvben az ICD-implantáció minden $30 \%$ alatti bal kamrai ejekciós frakciójú tünetmentes beteg esetében, mind iszkémiás, mind noniszkémiás etiológia esetén. Az irányelv ezen pontjával kapcsolatosan fontos megjegyezni, hogy míg iszkémiás etiológiájú tünetmentes szisztolés balkamra-diszfunkció esetén az ICD kedvező hatását illetően a MADIT II-vizsgálat (7) biztosít evidenciát, addig nem iszkémiás etiológiájú tünetmentes szisztolés balkamra-diszfunkció fennállásakor az ICD kedvező hatását illetően nem rendelkezünk bizonyítékokkal.

\section{A krónilkus HFrEF gyógyszeres kezelése}

Az új ESC-irányelv a HFrEF kezelésével kapcsolatban szóba jövő gyógyszeres terápiás lehetőségeket 5 kategóriába sorolja:

- Minden HFrEF-beteg számára javasolt gyógyszeres kezelések.

- Szelektált HFrEF-betegek számára javasolt gyógyszeres kezelések, amelyek kedvező hatása meggyőzően bizonyított. 
- További gyógyszeres kezelések, amelyek kedvező hatása kevésbé bizonyított.

- HFrEF-betegek számára nem javasolt gyógyszeres kezelések, mert kedvező hatásuk nem bizonyított.

- HFrEF-betegek számára nem javasolt gyógyszeres kezelések, mert alkalmazásuk veszélyes lehet.

\section{Minden HFrEF-beteg számára javasolt gyógyszeres kezelések}

A HFrEF-betegek kezelésében alkalmazott gyógyszereknek ebben a csoportjában nincs lényeges újdonság. $A z$ idetartozó ACE-inhibitorok (ACEi), bétareceptorblokkolók (BB) és mineralokortikoid-receptor-antagonisták (MRA) változatlanul a HFrEF-betegek kezelésének alappillérét képezik.

Az ACEi-okra vonatkozóan „A” típusú evidencián alapuló I. osztályú ajánlást fogalmaz meg a 2012-es és a 2016-os ESC, valamint a 2013-as ACCF/AHA-irányelv egyaránt, valamennyi HFrEF-betegre vonatkozóan (2. táblázat). Az irányelvek az ACEi-k kedvező hatását HFrEF-ben osztálytulajdonságnak tekintik, ezért bármely ACEi alkalmazását megengedhetőnek tartják.

Hasonlóan az ACEi-khez a BB-k esetében is mind a három irányelv minden HFrEF-beteg esetében "A" típusú evidencián alapuló I. osztályú ajánlást fogalmaz meg (2. táblázat). Különbség van azonban a javasolt a BB-k között. Míg az ESC-irányelvek a bisoprolol, a carvedilol, a metoprolol-szukcinát $\mathrm{CR} / \mathrm{XL}$ és a nebivolol alkalmazását egyaránt javasolják, addig az ACCF/AHA-ajánlásban a nebivolol nem szerepel. Ennek hátterében az áll, hogy míg a bisoprolol esetében a CIBIS II (8), a carvedilol esetében a US Carvedilol (9) és a COPERNICUS (10), s a metoprolol-szukcinát $\mathrm{CR} / \mathrm{XL}$ esetében a MERIT HF (11) placebokontrollos, randomizált tanulmányok a teljes vizsgált betegcsoportban összmortalitást csökkentő hatást bizonyítottak, addig a nebivololt vizsgáló SENIORS-tanulmányban (12) ez csak egy alcsoportban igazolódott.

Az MRA-k alkalmazását az ESC-irányelvek az ACEiés BB-kezelés ellenére panaszos betegek esetében javasolják (NYHA II-IV, LVEF $\leq 35 \%$ ) („A” típusú evidencián alapuló I. osztályú ajánlás) (2. táblázat). Az ACCF/AHA-irányelv az ESC-irányelv ajánlásán túl az EPHESUS-vizsgálat (13) evidenciáinak megfelelően külön javaslatot fogalmaz meg a miokardiális infarktuson átesett, LVEF $\leq 40 \%$ betegek esetében, amenynyiben szívelégtelenségre jellemző panaszaik vannak, vagy anamnézisükben diabetes mellitus szerepel („B" típusú evidencián alapuló I. osztályú ajánlás). Ismerve az MRA-k kedvező farmakológiai hatásait HFrEF-ben, a hyperkalaemia gondos ellenőrzése mellett, a gyógyszercsoport ACEi-khez és BB-khez hasonló széles körű alkalmazása indokoltnak tűnik.
Szelektált HFrEF-betegek számára javasolt gyógyszeres kezelések, amelyek kedvező hatása meggyőzően bizonyított

Ebbe a terápiás kategóriába olyan gyógyszerek, gyógyszercsoportok tartoznak, amelyek alkalmazásához nem elegendő csupán a HFrEF diagnózisa, hanem egyéb feltételek fennállása is szükséges. Ide tartoznak az angiotenzin-receptor neprilizin-inhibitorok (ARNI), az $\mathrm{I}_{\mathrm{f}}$-csatorna-blokkoló ivabradin, az angiotenzinreceptor-blokkolók (ARB), a direkt vazodilatátor (hydralazin+isosorbid-dinitrát) kombináció és a diuretikumok.

\section{Az ARNI-vegyületek első tagjának, az LCZ696 nevü} vegyületnek (sacubitril/valsartan) az enalaprilhoz képest megfigyelhető kedvező morbiditási, mortalitási hatását igazoló PARADIGM HF-vizsgálat (14) eredményeit 2014-ben, az előző ESC- és ACCF/AHA-irányelv megjelenését követően publikálták. Ennek megfelelően az LCZ696 új vegyületként szerepel az új ESC-irányelvben és az ACC/AHA/HFSA-irányelv megújitásban egyaránt. A két irányelv LCZ696-re vonatkozó ajánlása között nincs lényeges különbség. Az új ESC-irányelv a PARADIGM HF-vizsgálat besorolási kritériumait szem előtt tartva minden, optimális ACEi, BB, MRA-kezelés ellenére panaszos ambuláns HFrEF-beteg esetében javasolja az ACEi ARNI-ra történő váltását, aki legalább napi $2 \times 10 \mathrm{mg}$ enalaprilt tolerál és nátriuretikus peptidszintje emelkedett (BNP $\geq 100 \mathrm{pg} / \mathrm{ml}$ vagy NTproB$\mathrm{NP} \geq 400 \mathrm{pg} / \mathrm{ml}$ egy éven belül szívelégtelenség miatt hospitalizált, $B N P \geq 150 \mathrm{pg} / \mathrm{ml}$ vagy NTproBNP $\geq 600 \mathrm{pg} /$ $\mathrm{ml}$ egy éven belül szívelégtelenség miatt kórházi felvételre nem került betegek esetében) („B” típusú evidencián alapuló I. osztályú ajánlás). Az ACC/AHA/HFSA-irányelv megújítás az ACEi vagy ARB-kezelést toleráló, NYHA II-III funkcionális osztályú HFrEF-betegek számára javasolja az ACEi ARNI-ra történő cseréjét („B-R” típusú evidencián alapuló I. osztályú ajánlás) (a „B-R” evidencia az ACC/AHA/HFSA-irányelv megújításban 1 vagy több randomizált, kontrollált vizsgálat eredményein alapuló közepes minőségű evidenciát jelent) (2. táblázat).

Az új irányelvek minden bizonnyal az ARNI-vegyületek ideiglenes pozícióját határozzák meg az aktuális irányelvekben. Nem nagyon valószínủ ugyanis, hogy lesz egy olyan gyógyszercsoport (ARNI) a HFrEF-betegek kezelésében, amit úgy fogunk alkalmazni, hogy az egyik vegyületet (ACEi/ARB) optimális dózisig feltitráljuk, majd ezt követően lecseréljük egy másikra (ARNI). Tekintettel az LCZ696 ACEi-khoz képest megfigyelhető egyértelmű morbiditást és mortalitást csökkentő hatására, amennyiben az ARNI-k alkalmazása HFrEF-ben a teljes betegspektrumban biztonságosnak és effektívnek bizonyul, nagy valószínüséggel tanúi leszünk annak, hogy az ACEi/ARB-kezelést HFrEF-ben az ARNI-vegyületek váltják fel. $S$ nemcsak azoknál a betegeknél, akik tolerálják az optimális ACEi/ARB-dózist, hanem a HFrEF-betegek többségében a kezelését ACEi helyett ARNI alkalmazásával fogjuk kezdeni. 
Az ivabradin már szerepelt az előző 2012-ben publikált ESC-irányelvben is, tekintettel azonban arra, hogy az FDA-befogadás csak 2015-ben történt meg, a 2013es amerikai irányelv az ivabradint illetően még nem tett javaslatot, azonban új szerként szerepel a 2016-os ACC/AHA/HFSA-irányelv megújításban. A két irányelv az ivabradin alkalmazását illetően közel megegyező ajánlást fogalmaz meg. Az ESC-irányelvek az ivabradin kedvező hatását igazoló SHIFT-vizsgálat (15) besorolási kritériumait figyelembe véve minden optimális $A C E i$ (vagy $A R B$ ), MRA (vagy $A R B$ ) és céldózisú (vagy a maximálisan tolerált dózisban alkalmazott) BB-kezelés ellenére panaszos, sinusritmusban lévő, LVEF $\leq 35 \%$, szívfrekvencia $\geq 70 /$ min HFrEF-beteg számára javasolják az ivabradin alkalmazásának megfontolását (II.a osztályú ajánlás, „B” típusú evidencia) (2. táblázat). Hasonló kritériumok fennállása esetén BB-intoleráns betegekben az előző ESC-irányelv „C” típusú evidencián alapuló II.b osztályú ajánlást, az új ESC-irányelv „C” típusú evidencián alapuló II.a osztályú ajánlást fogalmaz meg.

Az ACC/AHA/HFSA-irányelv megújítás azon stabil, tünetes (NYHA II-III) HFrEF (LVEF $\leq 35 \%$ ) betegek esetében javasolja az ivabradin kezelés megfontolását, akik optimális gyógyszeres kezelésben részesülnek (beleértve a maximálisan tolerált dózisban alkalmazott BB-kezelést), sinusritmusban vannak és nyugalmi szívfrekvenciájuk $\geq 70 /$ min („B-R” típusú evidencián alapuló II.a osztályú ajánlás) (2. táblázat).

Mind a 2012-es és a 2016-os ESC, mind a 2013-as ACCF/AHA-irányelv két klinikai helyzetben tesz javas- latot az ARB-k alkalmazására. Az egyik az ACEi-intolerancia esete (döntően, amikor a beteg köhögés miatt ACEi-intolerans - a hipotónia, a vese funkcióromlás, illetve a hyperkalaemia angotenzin-Il szuppresszió okozta ACEi mellékhatások, ilyen esetekben nincs értelme ARB-re váltani), a másik az optimális ACEi- és BB-kezelés ellenére panaszos beteg, ha MRA-t valamiért nem kaphat. Mind a három irányelv I. osztályú ajánlásként fogalmazza meg, hogy ACEi-intolerancia esetén ARB-t kell alkalmazni, az evidenciaszint azonban a 2012-es ESC és a 2013-as ACCF/HA-irányelvben „A”, míg a 2016-os ESC-irányelvben „B” (2. táblázat). A második esetben (az optimális kezelés ellenére panaszos, MRA-kezelést nem toleráló betegek esetén) a 2012-es ESC-irányelvben „A” típusú evidencián alapuló I. osztályú ajánlás található, a 2013-as amerikai irányelvben az ajánlás II.b osztályú, az evidenciaszint „A”, míg a legújabb 2016-os ESC-irányelvben II.b osztályú az ajánlás erőssége és „C” típusú az evidenciaszint (2. táblázat). A nagy különbség nyilvánvalóan a 2012-es európai irányelv I. osztályú ajánlása és „A” evidencia szintje és a 2016-os ESC-irányelv II.b osztályú ajánlása és „C" evidencia szintje között van. Tekintettel arra, hogy az elmúlt 4-5 évben nem jelentek meg s különösen nem tűntek el releváns evidenciák, az ajánlás változása az ARB-k helyének újraértékelését jelzi a HFrEF kezelésében az evidenciák tükrében. Az idevonatkozó tanulmányok [VAL-HeFT (16), CHARM-Added (17), VALIANT (18)] közül egyik sem igazolta, hogy az ACEi+BB kezeléshez hozzáadott ARB csökkenti az összmortalitást, a CHARM-Added-vizsgálatban a primer végpontban (kardiovaszkuláris mortalitás+szívelégtelenség

2. TÁBLÁZAT. Az ajánlási osztályok és az evidenciaszintek összehasonlítása a 2016-ban, illetve a 2012-ben publikált ESC, valamint a 2013-ban megjelent ACCF/AHA szívelégtelenség irányelvben, illetve a 2016-ban publikált ACC/AHA/HFSA szívelégtelenség irányelv megújításban

\section{ESC 2016}

ACC/AHA/HFSA 2016

ESC 2012

ACCF/AHA 2013

Minden HFrEF-beteg számára javasolt gyógyszeres kezelések

\begin{tabular}{l|l|l|l|}
\hline ACEi & I. „A” & I. „A” & I. „A” \\
\hline BB & I. „A” & I. „A” & I. „A” \\
\hline MRA & I. „A” & I. „A” & I. „A”
\end{tabular}

Szelektált HFrEF-betegek számára javasolt gyógyszeres kezelések, amelyek kedvező hatása meggyőzően bizonyított

\begin{tabular}{|c|c|c|c|c|}
\hline ARNI & I. „B” & I. „B-R” & & \\
\hline Ivabradin & II.a „B” & II.a „B-R” & II.a „B” & \\
\hline $\begin{array}{l}\text { ARB (ACEi-intolerancia) } \\
\text { ARB (MRA-intolerancia) }\end{array}$ & $\begin{array}{l}\text { I. „B” } \\
\text { II.b”,C” }\end{array}$ & & $\begin{array}{l}\text { I. „A” } \\
\text { I. „A" }\end{array}$ & $\begin{array}{l}\text { I. „A” } \\
\text { II.b” „A" }\end{array}$ \\
\hline $\begin{array}{l}\text { DV (ACEi+ARB-intolerancia) } \\
\text { DV (OMT+DV) }\end{array}$ & $\begin{array}{c}\text { II.b „B” } \\
\text { II.a „B” (AA) }\end{array}$ & & $\begin{array}{l}\text { II.b „B” } \\
\text { II.b „B" }\end{array}$ & $\begin{array}{l}\text { II.a „B” } \\
\text { I. „A” (AA) }\end{array}$ \\
\hline Diuretikum & I. „B” & & & I. „C" \\
\hline \multicolumn{5}{|c|}{ További gyógyszeres kezelések, amelyek kedvező hatása kevésbé bizonyított } \\
\hline Digoxin & II.b „B” & & II.b „B” & II.a „B” \\
\hline PUFA & II.b „B” & & II.b „B” & II..a „B” \\
\hline
\end{tabular}

HFrEF: csökkent ejekciós frakciójú szívelégtelenség, ACEi: angiotenzin konvertáz enzim gátló, BB: bétareceptor-blokkoló, MRA: mineralokortikoid-receptor-antagonista, ARNI: angiotenzin-receptor neprilizin-inhibitor, ARB: angiotenzinreceptor-blokkoló, DV: direkt vazodilatátor kombináció, OMT: optimális gyógyszeres kezelés, AA: afro-amerikai betegekben, PUFA: többszörösen telítetlen zsírsavak 
miatti hospitalizáció) volt megfigyelhető szignifikáns rizikócsökkenés, a VAL-HeFT-vizsgálatban szignifikánsan csökkent a szívelégtelenség miatti hospitalizáció, míg a VALIANT-vizsgálatban a szívelégtelenség és a miokardiális infarktus miatti hospitalizáció rizikója. Az evidenciák tehát csak morbiditáscsökkenést igazoltak. $S$ mindemellett az alkalmazhatóságot jelentősen beszúkítette az MRA-k egyre kiszélesedő összmortalitás-csökkenést igazoló evidenciája, s az, hogy a három szer (ACEi+MRA+ARB) együtt alkalmazása a hyperkalaemia jelentős veszélye miatt kontraindikált. Mindezek alapján a jelenlegi ESC-irányelvben megfogalmazott, az ACCF/AHA-irányelvvel megegyező ajánlási erősség az evidenciákat figyelembe véve korrektebb és lényegesen jobban jellemzi az ARB-k helyét a HFrEF kezelésében, mint a korábbi irányelv ajánlása.

A direkt vazodilatátor (hyralazin+nitrát) kombináció (DV) alkalmazására mind az európai irányelvek, mind az amerikai irányelv két klinikai szituációban fogalmaz meg javaslatot. Részben azon betegek esetében, akik mind ACEi-ra, mind ARB-re intoleránsak (tehát minden olyan beteg esetében, akiknél az intolerancia oka hipotónia, vesefunkció-romlás, vagy hyperkalaemia), részben az optimális gyógyszeres kezelés (ACEi/ARB, BB és MRA/ARB) ellenére panaszos betegek esetében. $A z$ $A C E i+A R B$ intoleráns betegekre vonatkozó ajánlásban nincs különbség az előző és az új ESC-irányelv között (II.b ajánlás, „B” típusú evidencia). Az amerikai irányelv erősebb ajánlást fogalmaz meg (II.a ajánlás, „B” típusú evidencia) (2. táblázat). Tekintettel a DV-kezelést illető, a V-HeFT I-vizsgálatból (19) származó összmortalitást csökkentő evidenciára, az amerikai irányelvvel ebben a kérdésben jobban lehet azonosulni.

$A z$ optimális gyógyszeres kezelés (ACEi/ARB, BB és MRA/ARB) ellenére panaszos betegekre vonatkozó ajánlásban hosszú évek óta jelentős különbség figyelhető meg az európai és amerikai irányelvek között. Az A-HeFT-vizsgálat eredményei alapján az amerikai irányelv már régóta külön ajánlást fogalmaz meg az afro-amerikai betegeket illetően. A 2004-ben publikált A-HeFT-vizsgálat (20), amit a tervezett idő előtt befejeztek a kezelt csoportban megfigyelhető szignifikánsan alacsonyabb mortalitás miatt, ugyanis egyértelmúen igazolta egy magát afroamerikainak valló, az optimális ACEi+BB-kezelés ellenére NYHA III-IV. funkcionális osztálynak megfelelő tünetekkel bíró HFrEF (LVEF $\leq 35 \%$, vagy LVEF $\leq 45 \%$ és LVEDD $\geq 65 \mathrm{~mm}$, vagy LVEDDi $\geq 29 \mathrm{~mm} / \mathrm{m}^{2}$ ) betegcsoportban a direkt vazodilatátor kombináció szignifikáns összmortalitást csökkentő hatását (HR: 0,57, $p=0,01)$. Ennek megfelelően az amerikai irányelv „A” típusú evidencián alapuló I. osztályú ajánlást fogalmaz meg a direkt vazodilatátor kombináció alkalmazását illetően az A-HeFT-vizsgálatnak megfelelő betegpopulációban. A 2012-es európai irányelv rassztól függetlenül „B” típusú evidencián nyugvó II.b osztályú ajánlást adott a direkt vazodilatátor keze- lésre ebben a betegcsoportban, ami az A-HeFT-vizsgálat eredményei alapján nem igazán elfogadható. $A z$ új ESC-irányelv azonban már az amerikai irányelvnek megfelelően minden magát afroamerikainak valló, az optimális kezelés ellenére NYHA III-IV. funkcionális osztálynak megfelelő tünetekkel bíró HFrEF (LVEF $\leq 35 \%$, vagy LVEF $\leq 45 \%$ és LVEDD $\geq 65 \mathrm{~mm}$, vagy LVEDDi $\geq 29 \mathrm{~mm} / \mathrm{m}^{2}$ ) beteg esetében javasolja a DV-kezelés alkalmazásának megfontolását, csupán az ajánlás erőssége gyengébb az amerikai irányelvhez képest („B” típusú evidencia, Il.a osztályú ajánlás) (2. táblázat).

A diuretikumok alkalmazását illetően a 2012-es európai irányelv nem fogalmazott meg egyértelmű ajánlást, az új ESC-irányelvben I. osztályú ajánlást kapott a diuretikum kezelés pangásra jellemző tüneteket és panaszokat mutató betegek esetében a tünetek és a terhelhetőség javítását és II.a osztályú ajánlást a hospitalizáció csökkentését illetően („B” típusú evidencia). Az amerikai irányelv a diuretikum kezeléssel kapcsolatosan I. osztályú ajánlást fogalmaz meg a folyadékretencióval bíró betegek esetében („C” típusú evidencia) (2. táblázat).

\section{További gyógyszeres kezelések, amelyek kedvező hatása kevésbé bizonyított} A HFrEF-terápiában használatos gyógyszerek közül a digoxin és az N-3 PUFA tartoznak ebbe a csoportba.

A digoxin alkalmazását illetően nincs lényeges változás az ESC-irányelvekben. Sinusritmusban lévő betegek esetében, akik az optimális gyógyszeres kezelés ellenére ( $A C E i / A R B, B B$ és MRA/ARB) panaszosak maradnak mind a 2012-es, mind a 2016-os ESC-irányelv II.b osztályú ajánlást fogalmaz meg („B” típusú evidencia). Az amerikai irányelv ugyanebben a betegcsoportban II.a osztályú ajánlást ad („B” típusú evidencia) (2. táblázat)

A terápia omega-3 zsírsavakkal (N-3 PUFA) történő kiegészítése panaszos HFrEF-betegek esetében a jelenlegi és az előző ESC-irányelvben II.b osztályú ajánlás („B” típusú evidencia), az amerikai irányelvben II.a osztályú ajánlás („B” típusú evidencia) (2. táblázat).

\section{HFrEF-betegek számára nem javasolt gyógyszeres kezelések, mert kedvezó hatásuk nem bizonyított}

A statinok, az orális antikoagulánsok, a trombocitaaggregáció-gátlók és a direkt renin-inhibitorok alkalmazása nem javasolt HFrEF-ben, mivel kedvező hatásuk evidenciákkal nem alátámasztott, viszont e szerek többségének alkalmazása veszélyes mellékhatásokkal járhat.

A statinok (rosuvastatin) hatását két nagy vizsgálat (CORONA [21], GISSI HF [22]) értékelte HFrEF-ben. A CORONA-vizsgálatban (21) a rosuvastatin iszkémi- 
ás etiológiájú HFrEF-ben szignifikánsan csökkentette a kardiovaszkuláris hospitalizációt $(p<0,001)$, de nem csökkentette sem a mortalitást (HR: 0,95; $p=0,31)$, sem a koronária-végpontokat (HR: 0,$92 ; p=0,18)$. A GISSI HF-vizsgálat (22), amely részben iszkémiás, részben nem iszkémiás etiológiájú betegekben értékelte a rosuvastatin hatását, sem a mortalitás, sem a morbiditás vonatkozásában nem mutatott kedvező eredményt. Jelenleg a statinok alkalmazását illetően az a szakértői konszenzus, hogy csupán a HFrEF nem indokolja e szerek alkalmazását, azonban azoknál a betegeknél, akik a HFrEF diagnózisa előtt már koronáriabetegség, vagy hyperlipidaemia miatt statinkezelésben részesültek, a terápia folytatását meg kell fontolni.

Az orális antikoaguláns (OAC) kezeléssel kapcsolatban szintén nincs egyetlen olyan vizsgálat sem, amely az OAC-kezelés morbiditást, vagy mortalitást csökkentő hatását igazolta volna HFrEF-ben akár a placebóval, akár az aszpirinnel szemben. Ezért azokban az esetekben, ahol az OAC-kezelés egyéb indikációja nem áll fenn (pl. pitvarfibrilláció), a kezelés alkalmazása nem indokolt. A nem K-vitamin-antagonista új OAC (NOAC) kezelés hatását jelenleg folyó tanulmányok értékelik.

Mivel a trombocitaaggregáció-gátlók (TAG) vonatkozásában szintén nem rendelkezünk az alkalmazásukat alátámasztó evidenciákkal, a szakértők konszenzusa alapján csupán a HFrEF fennállása miatt nem javasolt alkalmazásuk. TAG-használat csak HFrEF mellett fennálló igazolt érbetegség esetén indokolt.

A direkt renin-inhibitor aliskirennel végzett vizsgálatok először akut szívelégtelenségben (ASTRONAUT) (23), majd krónikus szisztolés szívelégtelenségben is sikertelennek bizonyultak (ATMOSPHERE) (24). A 2016. áprilisban publikált ATMOSPHERE-vizsgálatban (24) sem az aliskiren sem az enalapril+aliskiren kombináció nem bizonyult non-inferiornak az enalaprilhoz képest. Azaz a primer végpont (kardiovaszkuláris mortalitás+szívelégtelenség miatti hospitalizáció) vonatkozásában nemcsak azt nem sikerült bebizonyítani, hogy az aliskiren önmagában, vagy az enalaprilhoz hozzáadva effektívebb lenne az enalaprilnál, de az egyenértékűség sem volt igazolható. $A z$ enalapril és az aliskiren együttes alkalmazása pedig szignifikánsan növelte a hyperkalaemia és a vesefunkció-károsodás előfordulását. Mindezek alapján úgy tünik, hogy a direkt renin-inhibitoroknak nem lesz helye a HFrEF kezelésében.

\section{HFrEF-betegek számára nem javasolt gyógyszeres kezelések, mert alkalmazásuk veszélyes lehet}

A thiazolidindionok (glitazonok), a NSAID-k és COX2-gátlók, a kalciumantagonisták a 3. generációs dihidropiridinek kivételével, valamint az ACEi+ARB+MRA kombináció alkalmazása bizonyítottan kedvezőtlen hatásaik miatt nem javasoltak HFrEF-ben.

\section{A HFrEF nem sebészi eszko̊zo̊s kezelésének újolonságai}

Az ICD-kezelésre vonatkozó ajánlások

A szekunder és primer prevenciós ICD alkalmazásra vonatkozó ajánlásokat illetően nincs lényeges újdonság az előző ESC-irányelvhez képest.

Szekunder prevenciós céllal minden hemodinamikai instabilitással járó kamrai ritmuszavart túlélő HFrEF-beteg esetében ICD-implantáció javasolt, amennyiben a beteg esetében egy évnél hosszabb jó funkcionális állapotú túlélés várható („A” típusú evidencián alapuló I. osztályú ajánlás).

Az új irányelv primer prevenciós céllal ICD-implantációt javasol (I. osztályú ajánlás) minden legalább három hónapos optimális gyógyszeres kezelésben részesülő, s ennek ellenére NYHA II-III. funkcionális osztályú, LVEF $\leq 35 \%$ beteg számára, mind iszkémiás („A” típusú evidencia), mind nem iszkémiás etiológiájú HFrEF esetén („B” típusú evidencia). Iszkémiás etiológiájú HFrEF-ben az ajánlás evidenciával egyértelmüen alátámasztott. A MADIT II-vizsgálat (7) 30\% alatti bal kamrai ejekciós frakciójú posztinfarktusos betegekben igazolta az ICD-alkalmazás összmortalitást csökkentő hatását. A SCD-HF-vizsgálat (25) szintén összmortalitás-csökkenést igazolt az ICD-alkalmazást illetően egy LVEF $\leq 35 \%$, NYHA II-III., részben iszkémiás, részben noniszkémiás betegcsoportban. Az etiológia szerinti alapcsoport-analízis azonban csak az iszkémiás alcsoportban mutatott statisztikailag szignifikáns összmortalitás-csökkenést. A non-iszkémiás etiológiájú betegek esetében tehát nincs igazán meggyőző evidencia. Ezen túlmenően az új ESC-irányelv publikációját követően jelent meg egy újabb tanulmány (DANISH-vizsgálat) (26), ami LVEF $\leq 35 \%$, NYHA II-IV., NTproBNP>200 $\mathrm{pg} / \mathrm{ml}$, nem iszkémiás etiológiájú HFrEF-ben szenvedő betegcsoportban az ICD-alkalmazás kapcsán nem igazolt összmortalitás-csökkenést. Csupán a hirtelen halál vonatkozásában volt megfigyelhető szignifikáns rizikócsökkenés, ami a változatlan arányú összmortalitás és kardiovaszkuláris mortalitással együtt, a halál módjának megváltozására utal, azaz felveti a lehetőségét annak, hogy ezek a beteg nem hirtelen, hanem pl. progresszív szívelégtelenségben halnak meg. Az összmortalitást tekintve csak a betegek 68 évnél fiatalabb alcsoportjában volt szignifikáns rizikócsökkenés kimutatható. Mindezek az adatok arra utalnak, hogy az új irányelvnek ez az ajánlása a következő irányelvekben minden bizonnyal módosításra szorul.

Az új irányelvben újdonság, hogy egyértelműen kontraindikációként jelöli meg az ICD alkalmazását a miokardiális infarktust követő 40 napos periódusban (III. osztályú ajánlás, „A” típusú evidencia), illetve NYHA IV. funkcionális stádiumú, gyógyszeres kezelésre re- 
frakter, CRT-kezelésre, mechanikus keringéstámogató kezelésre és szívtranszplantációra alkalmatlan betegek esetében (III. osztályú ajánlás, „C” típusú evidencia). Az utóbbi ajánlás hátterét az jelenti, hogy a súlyos, előrehaladott szívelégtelenségben szenvedő betegek esetében az ICD-terápia csupán a halál módját shifteli a hirtelen halál felöl a progresszív szívelégtelenség irányában, de nem változtatja meg az összmortalitást. Ugyancsak új ajánlás vonatkozik az új irányelvben a kimerülő ICD-generátorok cseréjét megelőző megfontolásokra. Fontos, hogy az új generátor beültetése előtt tapasztalt kardiológus hozzon döntést a készülék típusát illetően, hiszen az előző ICD implantációja óta jelentős változás történhetett a beteg állapotában, sőt a beteg preferenciáiban is. PI. végstádiumú szívelégtelenségben szenvedő beteg esetében az előbb említett megfontolások miatt nem biztos, hogy újabb ICD-generátor visszaültetése szükséges (II.a osztályú ajánlás, „B” típusú evidencia).

Újdonság az új irányelvben a testen kívül viselhető ICD-k megjelenése, olyan esetekben, amikor a hirtelen halál rizikója az adott beteg életének csak egy rövid szakaszában emelkedett (myocarditis, peripartum cardiomyoptahia stb.) (II.b osztályú ajánlás, „C” típusú evidencia)

\section{A CRT alkalmazásra vonatkozó ajánlások}

A CRT alkalmazást illetően a legerősebb az ajánlás és az evidenciaszint sinusritmusban lévő, LVEF $\leq 35 \%$, QRS $\geq 150$ msec, LBBB QRS morfológiájú HFrEF betegekben (I. osztályú ajánlás, „A” típusú evidencia). Valamivel gyengébb az evidencia, de ugyanolyan erős az ajánlás a fenti betegcsoportban 130-149 msec közötti QRS szélesség esetén (I. osztályú ajánlás, „B” típusú evidencia), ami azt jelenti, hogy valamennyi 130 msecnál szélesebb QRS-ü, LBBB QRS-morfológiát mutató, LVEF $\leq 35 \%$, sinusritmusban lévő betegnek kardiális reszinkronizációs kezelésben kell részesülnie.

Az új irányelv ajánlása szerint a CRT-alkalmazást meg kell fontolni minden sinusritmusban lévő, LVEF $\leq 35 \%$, QRS $\geq 150$ msec, nem LBBB QRS-morfológiájú HFrEF-beteg esetében (II.a osztályú ajánlás, „B” típusú evidencia), és meg lehet fontolni minden sinusritmusban lévő, LVEF $\leq 35 \%, 130-149$ közötti QRS-sel bíró, nem LBBB QRS-morfológiájú HFrEF-beteg esetében (II.b osztályú ajánlás, „B” típusú evidencia).

Pitvarfibrilláló betegekben, LVEF $\leq 35 \%$ QRS $\geq 130 \mathrm{msec}$ és NYHA III-IV. funkcionális osztálynak megfelelő panaszok esetén szintén meg kell fontolni a CRT alkalmazását (II.a osztályú ajánlás, „B” típusú evidencia), ami mellett azonban fontos biztosítani az optimális BiV pacelési arányt.

Azon HFrEF-betegek esetében, akiknél konvencionális pacemaker- vagy ICD-alkalmazás mellett magas arányú jobb kamrai pacelés észlelhető, s az optimális gyógyszeres kezelés ellenére progrediáló szívelégtelenségre jellemző panaszaik, tüneteik vannak a CRT upgrade megfontolható (II.b osztályú ajánlás, „B” típusú evidencia). Jelenleg folyamatban van a BUDAPEST CRT-vizsgálat (27), amely további fontos evidenciákat szolgáltathat ebben a vonatkozásban.

Két igazi újdonsága van az új irányelv CRT-alkalmazásra vonatkozó fejezetének. Az egyik az előző ESC-irányelv megjelenését követően, 2013-ban publikált BLOCK HF-vizsgálat (28) eredményét tükrözi, amely LVEF $\leq 50 \%$, magasfokú AV-blokk miatt konvencionális pacemaker-indikációval rendelkező betegek csoportjában igazolta a CRT-kezelés mortalitást és morbiditást csökkentő hatását a jobb kamrai pacemaker-kezeléshez képest. Ennek megfelelően az új irányelv „A” típusú evidencián alapuló I. osztályú ajánlást fogalmaz meg a CRT-alkalmazást illetően a jobb kamrai paceléssel szemben minden magas fokú AV-blokk miatt konvencionális pacemaker-indikációval rendelkező HFrEF-beteg esetében a NYHA funkcionális osztálytól függetlenül.

A másik újdonság a szintén 2013-ban publikált ECHO-CRT-vizsgálat (29) eredményén nyugszik, ami 130 msec-nál keskenyebb QRS-ü, mechanikus asyncronia jeleit mutató, LVEF $\leq 35 \%$, LVEDD $\geq 55 \mathrm{~mm}, \mathrm{NYHA}$ III-IV. betegcsoportban a CRT-alkalmazás összmortalitást növelő hatását bizonyította. Ennek következtében az új irányelvben a CRT alkalmazása 130 msec-nál keskenyebb QRS-ü betegek esetében kontraindikációként szerepel (III. osztályú ajánlás, „A” típusú evidencia).

\section{A HFpEF kezelése}

A HFpEF vonatkozásában az új ESC-irányelv az első, amely a diagnosztikus kritériumok között a szívelégtelenségre jellemző tünetek és panaszok, a megtartott ejekciós frakció (LVEF $\geq 50 \%$ ) s az echokardiogáfiával meghatározott releváns szívbetegség vagy diasztolés diszfunkció mellett már az emelkedett nátriuretikus peptidszintet is megemlíti. Mindeddig azonban ez utóbbi hiányában és a diasztolés balkamra-diszfunkció meglehetősen komplex meghatározhatósága miatt mind az epidemiológiai vizsgálatokban, mind a klinikai vizsgálatok többségében besorolási kritériumként kizárólag a szívelégtelenségre jellemző tünetek és panaszok, valamint a megtartott LVEF szerepeltek, ami meglehetősen heterogén betegcsoport besorolását jelentette mind a két típusú vizsgálatba. Nagyszámban szerepeltek tüdőbetegség, obesitas, idős életkor, illetve edzetlenség miatt effort dyspnoet panaszoló betegek tényleges diasztolés diszfunkció, tényleges HFpEF nélkül.

Az eddigi HFpEF-betegcsoportban végzett vizsgálatok (PEP-CHF [30], I-PRESERVE [31], CHARM-Preserved [32], DIG Ancillary [33], SENIORS [34], TOPCAT [35]), amelyek felépítése a fentieknek megfelelően meglehetősen kritizálható, nem eredményeztek szignifikáns rizikó csökkenést a tanulmányok primer végpontjaiban, s a meghatározó jelentőségű mortalitási végpontokban. 


\section{Ennek megfelelően az új ESC-irányelv meglehetősen szükszavúan fogalmaz a HFpEF-betegek kezelését illetően: minden beteg esetében keresni kell a kardio- vaszkuláris és nem kardiovaszkuláris társbetegsége- ket, s ezeket a szakmai irányelveknek megfelelően kell kezelni, valamint diuretikumot kell alkalmazni a folya- dékretencióval rendelkező betegeknél.}

\section{Irodalom}

1. Ponikowski P, Voors AA, Anker SD et al. 2016 ESC Guidelines for the diagnosis and treatment of acute and chronic heart failure: The Task Force for the diagnosis and treatment of acute and chronic heart failure of the European Society of Cardiology (ESC) Developed with the special contribution of the Heart Failure Association (HFA) o the ESC. Eur Heart J 2016; 37: 2129- 2200. Doi 10.1093/eurheartj ehw128

2. Yancy CW, Jessup M et al. 2016 ACC/AHA/HFSA Focused Update on New Pharmacological Therapy for Heart Failure: An Update of the 2013 ACCF/AHA Guideline for the Management of Heart Failure. $J$ Am Coll Cardiol 2016; 68: 1476-88. Doi 10.1016/j.jacc.2016.05.011 3. McMurray JJV, Adamopoulos S, Anker SD et al. ESC Guidelines for the diagnosis and treatment of acute and chronic heart failure 2012 The Task Force for the Diagnosis and Treatment of Acute and Chronic Heart Failure 2012 of the European Society of Cardiology. Developed in collaboration with the Heart Failure Association (HFA) of the ESC. Eur Heart J 2012; 33: 1787-847. Doi 10.1093/eurheartj/ehs104

4. Yancy CW, Jessup M et al. 2013 ACCF/AHA guideline for the management of heart failure: a report of the American College of Cardiology Foundation/American Heart Association Task Force on practice quidelines. Circulation 2013; 128: 240-327. Doi 10.1161/CIR ob013e31829e8807

5. Zinman B et al. Empagliflozin, Cardiovascular Outcomes, and Mortality in Type 2 Diabetes. N Engl J Med. 2015; 373: 2117-28. Doi 10.1056/NEJMoa1504720

6. The CAPRICORN Investigators. Effect of carvedilol on outcome after myocardial infarction in patients with left-ventricular dysfunction: the CAPRICORN randomised trial. Lancet 2001; 357: 1385-90. doi 10.1016/S0140-6736(00)04560-8

7. Moss AJ, Zareba W, Hall WJ et al. Prophylactic implantation of a defibrillator in patients with myocardial infarction and reduced ejection fraction. N Eng J Med 2002; 346: 877-83. Doi 10.1056/NEJ. Moa013474

8. CIBIS II Investigators and Committees. The Cardiac Insufficiency Bisoprolol Study II (CIBIS II): a randomised trial. Lancet 1999; 353 9-13. Doi 10.1016/S0140-6736(98)11181-9

9. Packer M, Bristow MR, Cohn JN et al. for the U.S. Carvedilol Hear Failure Study Group. The Effect of carvedilol on morbidity an mortality in patients with chronic heart failure. N Eng J Med 1996; 334: 134955. Doi 10.1056/NEJM199605233342101

10. Packer M, Coats A, Fowler MB et al. Effect of carvedilol on survival in severe chronic heart failure. N Eng J Med 2001; 344: 1651-58. Doi 10.1056/NEJM200105313442201

11. MERIT HF Study Group. Effect of metoprolol CR/XL in chronic heart failure: Metoprolol CR/XL Randomised Intervention Trial in Congestive Heart Failure (MERIT-HF). Lancet 1999; 353: 2001-07. Doi 10.1016/S0140-6736(99)04440-2

12. Flather MD, Shibata MC, Coats AJS et al. Randomized trial to de termine the effect of nebivolol on mortality and cardiovascular hospita admission in elderly patients with heart failure (SENIORS). Eur Heart J 2005; 26: 215-25. Doi 10.1093/eurheartj/ehi115

13. Pitt B, Remme W, Zannad F et al. Eplerenone, a selective aldosterone blocker, in patients with left ventricular dysfunction after myocardial infarction. N Eng J Med 2003; 348: 1309-21. Doi 10.1056/NEJMoa030207

14. McMurray JJV, Packer M, Desai AS et al. Angiotensin-neprilysin inhibition versus enalapril in heart failure. N Eng J Med 2014; 371 : 993-1004. Doi 10.1056/NEJMoa1409077

15. Swedberg K, Komajda M, Böhm M et al. Ivabradine and outcomes in chronic heart failure (SHIFT): a randomised placebo-controlled study. Lancet 2010; 376:875-85. Doi 10.1016/S0140-6736(10)61198-1 16. Cohn JN, Tognoni G. A randomized trial of the angiotensin-recep- tor blocker valsartan in chronic heart failure. N Eng J Med 2001; 345: 1667-75. Doi 10.1056/NEJMoa010713

17. McMurray JJ, Östergren J, Swedberg K et al. Effects of candesartan in patients with chronic heart failure and reduced left ventricular systolic function taking angiotensin-converting-enzyme inhibitors: the CHARM-Added trial. Lancet 2003; 362: 767-71. Doi 10.1016/S01406736(03)14283-3

18. Pfeffer MA, McMurray JJ, Velazquez EJ et al. Valsartan, captopril, or both in myocardial infarction complicated by heart failure, left ventricular dysfunction, or both. N Eng J Med 2003; 349: 1893-906. Doi 10.1056/NEJMoa032292

19. Cohn JN, Archibald DG, Ziesche S, Franciosa JA, Hartson WE, Tristani FE. Effect of vasodilator therapy on mortality in chronic congestive heart failure: results of a Veterans Administration Cooperative Study. N Engl J Med 1986; 314: 1547-52. Doi 10.1056/ NEJM198606123142404

20. Taylor AL, Ziesche S, Yancy C, Carson P, D'Agostino R Jr, Fer dinand $\mathrm{K}$, et al. African-American Heart Failure Trial Investigators: Combination of isosorbide-dinitrate and hydralazine in blacks with heart failure. N Eng J Med 2004; 351: 2049-57. Doi 10.1056/NEJMoa042934

21. Kjekshus J, Apetrei E, Barrios V et al. Rosuvastatin in Older Patients with Systolic Heart Failure. N Eng J Med 2007; 357: 2248-61. Doi 10.1056/NEJMoa0706201

22. GISSI-HF Investigators. Effect of rosuvastatin in patients wirh chronic heart failure (GISSI-HF trial): a randomised, double-blind, placebo-controlled trial. Lancet 2008; 372: 1230-39. Doi 10.1016/S01406736(08)61240-4

23. Gheorghiade M, Böhm M, Greene SJ et al. Effect of aliskiren on postdischarge mortality and heart failure readmissions among patients hospitalized for heart failure: the ASTRONAUT randomized trial. JAMA 2013; 309: 1125-35. Doi 10.1001/jama.2013.1954

24. McMurray JJ, Krum H, Abraham WT et al. Aliskiren, Enalapril, or Aliskiren and Enalapril in Heart Failure. N Engl J Med 2016; 374 1521-32. Doi 10.1056/NEJMoa1514859

25. Brady GH, Lee KL, Mark DB et al. Amiodarone or an implantable cardioverter-defibrillator for congestive heart failure. N Eng J Med 2005; 352: 225-237. Doi 10.1056/NEJMoa043399

26. Køber L, Thune JJ, Nielsen JC et al. Defibrillator Implantation in Patients with Nonischemic Systolic Heart Failure. N Engl J Med 2016 375: 1221-30. Doi 10.1056/NEJMoa1608029

27. Merkely B, Kosztin A, Roka A et al. Rationale and design of the BUDAPEST-CRT upgrade study: a prospective, randomized, multicentre clinical trial. Europace 2016 Oct 6. doi: 10.1093/europace euw193. [Epub ahead of print] Doi 10.1093/europace/euw193 28. Curtis AB, Worley SJ, Adamson PB et al. Biventricular Pacing for Atrioventricular Block and Systolic Dysfunction. N Eng J Med 2013 368: 1585-93. Doi 10.1056/NEJMoa1210356

29. Ruschitzka F, Abraham WT, Singh JP et al. Cardiac-Resynchronization Therapy in Heart Failure with a Narrow QRS Complex. N Eng J Med 2013; 369: 1395-405. Doi 10.1056/NEJMoa1306687

30. Cleland JGF, Tendera M, Adamus J et al. The perindopril in elderly people with chronic heart failure (PEP-CHF) study. Eur Heart J 2006; 27: 2338-45. Doi 10.1093/eurheartj/ehl250

31. Massie BM, Carson PE, McMurray JJ et al. Irbesartan in patients with heart failure and preserved ejection fraction. N Eng J Med 2008 359: 2456-2467 Doi 10.1056/NEJMoa0805450

32. Yusuf S, Pfeffer MA, Swedberg K et al. Effects of candesartan in patients with chronic heart failure and preserved left-ventricular ejection fraction: the CHARM-Preserved Trial. Lancet 2003; 362: 777-781. Doi 10.1016/S0140-6736(03)14285-7

33. Ahmed A, Rich MW, Fleg JL et al. Effects of digoxin on morbidity and mortality in diastolic heart failure: the ancillary digitalis investigation group trial. Circulation 2006; 114: 397-403. Doi 10.1161/CIRCUATIONAHA.106.628347

34. Veldhuisen DJ, Cohen-Solal A, Böhm M et al. Beta-blockade with nebivolol in elderly heart failure patients with impaired and preserved left ventricular ejection fraction. J Am Coll Cardiol 2009; 53: 2150 2158. Doi 10.1016/j.jacc.2009.02.046

35. Pitt B, Pfeffer MA, Assmann SF et al. Spironolactone for Heart Failure with Preserved Ejection Fraction. N Eng J Med 2014; 370: 1383 1392. Doi 10.1056/NEJMoa1313731 